\title{
Constraints on ocean circulation at the Paleocene-Eocene Thermal Maximum from neodymium isotopes
}

\author{
April N. Abbott ${ }^{1, \mathrm{a}}$, Brian A. Haley ${ }^{1,2}$, Aradhna K. Tripati ${ }^{3,4}$, and Martin Frank ${ }^{2}$ \\ ${ }^{1}$ CEOAS, OSU, 104 CEOAS Admin. Bldg., Corvallis, OR 97209, USA \\ ${ }^{2}$ GEOMAR Helmholtz Centre for Ocean Research Kiel, Wischhofstraße 1-3, 24148 Kiel, Germany \\ ${ }^{3}$ Department of Earth and Space Sciences, Department of Atmospheric and Oceanic Sciences, and \\ Institute of the Environment and Sustainability, University of California, Los Angeles, CA 90095, USA \\ ${ }^{4}$ European Institute of Marine Sciences (IUEM), Université de Brest, UMR 6538, Domaines Océaniques, \\ Rue Dumont D’Urville, Plouzané, France \\ ${ }^{a}$ now at: Macquarie University, Department of Earth and Planetary Sciences, North Ryde, Sydney, \\ NSW 2109, Australia
}

Correspondence to: Brian A. Haley (bhaley@ coas.oregonstate.edu)

Received: 5 May 2015 - Published in Clim. Past Discuss.: 30 June 2015

Revised: 18 February 2016 - Accepted: 6 March 2016 - Published: 7 April 2016

\begin{abstract}
Global warming during the Paleocene-Eocene Thermal Maximum $($ PETM $) \sim 55$ million years ago $(\mathrm{Ma})$ coincided with a massive release of carbon to the oceanatmosphere system, as indicated by carbon isotopic data. Previous studies have argued for a role of changing ocean circulation, possibly as a trigger or response to climatic changes. We use neodymium $(\mathrm{Nd})$ isotopic data to reconstruct short high-resolution records of deep-water circulation across the PETM. These records are derived by reductively leaching sediments from seven globally distributed sites to reconstruct past deep-ocean circulation across the PETM. The Nd data for the leachates are interpreted to be consistent with previous studies that have used fish teeth $\mathrm{Nd}$ isotopes and benthic foraminiferal $\delta^{13} \mathrm{C}$ to constrain regions of convection. There is some evidence from combining $\mathrm{Nd}$ isotope and $\delta^{13} \mathrm{C}$ records that the three major ocean basins may not have had substantial exchanges of deep waters. If the isotopic data are interpreted within this framework, then the observed pattern may be explained if the strength of overturning in each basin varied distinctly over the PETM, resulting in differences in deep-water aging gradients between basins. Results are consistent with published interpretations from proxy data and model simulations that suggest modulation of overturning circulation had an important role for initiation and recovery of the ocean-atmosphere system associated with the PETM.
\end{abstract}

\section{Introduction}

The Paleocene-Eocene Thermal Maximum (PETM) represents a time of profound global change with deep-sea temperatures increasing 4-8 ${ }^{\circ} \mathrm{C}$ (Katz et al., 1999; Kennett and Stott, 1991; Sluijs et al., 2006; Tripati and Elderfield, 2004, 2005; Zachos et al., 2001, 2003, 2006), widespread biological extinctions (e.g., Kennett and Stott, 1991), and ocean acidification marked by widespread carbonate dissolution occurring $\sim 55 \mathrm{Ma}$ (Dickens, 2000; Kump et al., 2009; Ridgwell and Schmidt, 2010; Zachos et al., 2005, 2008; Zeebe and Zachos, 2007). In general, the timing and global distribution of temperature records across the PETM are consistent with strong greenhouse forcing (Kennett and Stott, 1991; Tripati and Elderfield, 2004, 2005; Zachos et al., 2001, 2003; Sluijs et al., 2007), although the amount of carbon released, the type of carbon (Zeebe et al., 2009), and the possible role of other forcing agents (e.g., water vapor, aerosol loading, surface albedo feedbacks) is unclear (Bowen et al., 2004; Lunt et al., 2012; Higgins and Schrag, 2006). Changes in deepocean circulation, orbital cycles, and direct and indirect volcanic activity exhalations are proposed causes of the initial warming (e.g., Kennett and Stott, 1991; Bice and Marotzke, 2002; Dickens et al., 1995; Lunt et al., 2011, 2012; McInerney and Wing, 2011; Nunes and Norris, 2006; Sluijs et al., 2007; Tripati and Elderfield, 2005; Winguth et al., 2010; 
Zachos et al., 2001; Higgins and Schrag, 2006; Svensen et al., 2004; Storey et al., 2007). Climate simulations even suggest that the magnitude and pacing of the PETM and subsequent smaller events (ETM2 and ETM3) can be explained by orbitally induced changes in water temperature and circulation controlling the destabilization of methane hydrates (e.g., Lunt et al., 2010).

A striking characteristic of the PETM is a pronounced global negative stable carbon isotope $\left(\delta^{13} \mathrm{C}\right)$ excursion (CIE) (Kennett and Stott, 1991; Koch et al., 1992; Bowen et al., 2001; Nunes and Norris, 2006; McCarren et al., 2008; McInerney and Wing, 2011; Zachos et al., 2001). This isotopic excursion resulted from a rapid release (in less than 10000 years) of carbon from an isotopically light reservoir, likely resulting from the warming climate (e.g., Farley and Eltgroth, 2003; Murphy et al., 2010; Röhl et al., 2007). Based on basinal gradients of available benthic $\delta^{13} \mathrm{C}$ data (Nunes and Norris, 2006; Tripati and Elderfield, 2005), widespread carbonate dissolution (Dickens, 2000; Kump et al., 2009; Ridgwell and Schmidt, 2010; Zachos et al., 2005, 2008), inferred deep-sea carbonate ion gradients (Zeebe and Zachos, 2007), as well as numerical modeling studies (Bice and Marotzke, 2002; Lunt et al., 2012), it has been argued that a change in thermohaline circulation may have been associated with the PETM. Such studies have postulated circulation regimes fundamentally different than the modern ocean operating before and after the PETM (Kennett and Stott, 1991; Lunt et al., 2011). Specifically, studies have proposed the existence of "Southern Ocean" (herein "Southern Ocean" is used to distinguish from the modern contiguous Southern Ocean that surrounds Antarctica) deep-water formation (Kennett and Stott, 1991) based on high-resolution carbon isotope records that are used to infer basinal deepwater aging gradients (Nunes and Norris, 2006; Tripati and Elderfield, 2005) and have suggested intermittent deep-water formation in the North Pacific based on a fully coupled atmosphere-ocean general circulation model based on $p \mathrm{CO}_{2}$ simulations (Lunt et al., 2011). It is hypothesized that, due to gradual changes in the temperature and hydrology of highlatitude surface waters, these southern-sourced waters were displaced during the PETM with the development of convection in the Northern Hemisphere (Bice and Marotzke, 2002; Tripati and Elderfield, 2005; Nunes and Norris, 2006; Alexander et al., 2015). The combination of warmer deepwater and circulation changes may have served as a trigger or amplifier of the massive carbon release that resulted in the global CIE, possibly through the destabilization of methane hydrates (e.g., Bice and Marotzke, 2002; Lunt et al., 2011).

However, interpreting past benthic $\delta^{13} \mathrm{C}$ records in benthic foraminifera of the PETM as a strict indicator of thermohaline circulation is complicated by possible contributions of fractionated carbon sources (Kurtz et al., 2003), changes in marine productivity (Paytan et al., 2007), deep-water carbon export (McCarren et al., 2008), extinction and migration events of the biota, and potential signal loss through dissolution in highly corrosive bottom waters (Alexander et al., 2015; McCarren et al., 2008; Pagani et al., 2006; Zeebe and Zachos, 2007). In contrast, the geochemical cycling of neodymium $(\mathrm{Nd})$ in the oceans allows $\mathrm{Nd}$ isotopes to be used as a quasi-conservative tracer of water mass distributions that is generally not affected by biogeochemical processes that can be used to reconstruct past ocean circulation (e.g., Frank, 2002; Goldstein et al., 2003; Thomas, 2004).

Published records of past seawater Nd isotope compositions $\left(\varepsilon_{\mathrm{Nd}}\right)$ extracted from fossil fish teeth serve as a proxy for past deep-water mass distributions and mixing and do not show clear evidence for changes at the PETM. Specifically, the low-resolution $\varepsilon_{\mathrm{Nd}}$ data from fish teeth have been interpreted as possibly reflecting an uninterrupted contribution from a Southern Ocean deep-water source in multiple basins across the PETM (Thomas et al., 2003). This apparent disparity between proxy data may reflect the non-conservative nature of interpreting benthic foraminiferal $\delta^{13} \mathrm{C}$, or could arise from the low-resolution nature of the published Nd isotope records.

To address whether there is $\mathrm{Nd}$ isotope evidence for changes in water mass distributions, we developed highresolution records of the $\varepsilon_{\mathrm{Nd}}$ composition of $\mathrm{Fe}-\mathrm{Mn}$ leachates from seven sites and compare these results to published $\varepsilon_{\mathrm{Nd}}$ data for fish teeth (Thomas et al., 2003) and benthic foraminiferal $\delta^{13} \mathrm{C}$ (Nunes and Norris, 2006; Tripati and Elderfield, 2005; Zachos et al., 2001). The Nd isotope composition of $\mathrm{Fe}-\mathrm{Mn}$ oxide leachates from core-top sediments has been used to accurately reconstruct bottom water values (Rutberg et al., 2000; Bayon et al., 2002; Gutjahr et al., 2007). This technique has also been applied to downcore sediments to study variations in bottom water circulation during the Pleistocene (Rutberg et al., 2000; Piotrowski et al., 2004, 2005, 2008). Measurements on older sediments ranging from Cenozoic (Martin et al., 2010) to Cretaceous (Martin et al., 2012) in age have shown that sequences from multiple localities can preserve a $\mathrm{Nd}$ isotope signal similar to fish teeth and can be used to develop high-resolution paleoceanographic records.

\section{Materials and methods}

\subsection{Sample and locality information}

Details on the core locations, depths, and paleodepths are given in Table 1. Sites were located at similar water depths during the PETM, with paleodepths between 2400 and $3200 \mathrm{~m}$ in the Pacific, between 1900 and $2000 \mathrm{~m}$ in the North Atlantic, and between 1900 and $3400 \mathrm{~m}$ in the Southern and Indian oceans (Table 1). Sources for the carbon isotope data referred to in this study are reported in this table. The age models used to plot all the data (including $\delta^{13} \mathrm{C}$ ) are shown in Table 2, and are derived from the information given in the publications of the $\delta^{13} \mathrm{C}$ data (Thomas et al., 2003; Nunes and Norris, 2006; Tripati and Elderfield, 2005). For com- 
Table 1. Core information; all cores were collected as part of the Deep Sea Drilling Program (DSDP) and the Ocean Drilling Program (ODP).

\begin{tabular}{lrrrrl}
\hline Core & \multicolumn{2}{l}{ Modern latitude, longitude, and depth $(\mathrm{m})$} & Paleodepth $(\mathrm{m})$ & $\delta^{13} \mathrm{C}$ data reference \\
\hline 213 & $10^{\circ} 12.7^{\prime} \mathrm{S}$ & $93^{\circ} 53.7^{\prime} \mathrm{E}$ & 5601 & 3000 & Thomas et al. (2003) \\
401 & $47^{\circ} 25.7^{\prime} \mathrm{N}$ & $8^{\circ} 48.6^{\prime} \mathrm{W}$ & 2495 & 1900 & Thomas et al. (2003) \\
527 & $28^{\circ} 2.5^{\prime} \mathrm{S}$ & $1^{\circ} 45.8^{\prime} \mathrm{E}$ & 4428 & 3400 & Thomas et al. (2003) \\
$690 \mathrm{~B}$ & $65^{\circ} 9.6^{\prime} \mathrm{S}$ & $1^{\circ} 12.3^{\prime} \mathrm{E}$ & 2914 & 1900 & Thomas et al. (2003) \\
1051B & $30^{\circ} 3.2^{\prime} \mathrm{N}$ & $76^{\circ} 21.5^{\prime} \mathrm{W}$ & 1981 & 2000 & Thomas et al. (2003) \\
1209B & $32^{\circ} 39.1^{\prime} \mathrm{N}$ & $158^{\circ} 30.4^{\prime} \mathrm{E}$ & 2387 & 2400 & Tripati and Elderfield (2005) \\
1220B & $10^{\circ} 10.6^{\prime} \mathrm{N}$ & $142^{\circ} 45.5^{\prime} \mathrm{W}$ & 5218 & 3200 & Tripati and Elderfield (2005) \\
\hline
\end{tabular}

Table 2. Age models.

\begin{tabular}{lcrrrr}
\hline \multirow{2}{*}{ Core } & Age model segment & \multicolumn{2}{c}{ Core depth (mbsf) } & \multicolumn{2}{c}{ Curve definition } \\
\cline { 2 - 6 } & & start & end & $m$ & $b$ \\
\hline \multirow{2}{*}{$1209 \mathrm{~B}$} & a & 210.72 & 211.24 & 0.3539 & -19.317 \\
213 & b & 211.26 & 211.40 & 2.5000 & -472.660 \\
& a & 145.13 & 147.35 & 0.2541 & +17.727 \\
401 & b & 147.41 & 147.64 & 0.1193 & +37.590 \\
& a & 198.54 & 201.97 & 0.1640 & +22.054 \\
$1220 B$ & b & 202.02 & 202.98 & 0.0656 & +41.922 \\
& a & 197.55 & 199.20 & 0.4009 & -24.697 \\
& b & 199.25 & 199.93 & 0.0955 & +36.159 \\
$690 B$ & a & 199.63 & 200.71 & 0.2027 & +14.491 \\
& b & 200.89 & 202.76 & 0.0700 & +41.129 \\
& a & 162.80 & 170.69 & 0.0646 & +44.199 \\
& b & 170.71 & 170.76 & 0.0453 & +47.528 \\
1051B & c & 170.84 & 172.49 & 0.1923 & +22.416 \\
& d & 172.95 & 179.80 & 0.1167 & +35.192 \\
& a & 510.17 & 512.35 & 0.1164 & -4.439 \\
& b & 512.40 & 513.80 & 0.2100 & -52.412 \\
\hline
\end{tabular}

pleteness, we show in Table 2 the core depth-age curve fits that describe the age models for each core, where

Age $(\mathrm{Myr})=m($ core depth in $\mathrm{mbsf})+b$.

Several segments are listed if sedimentation rates varied downcore (the depth ranges of these segments are listed in Table 2). In all cases, simple linear sedimentation rates were used. These age models were also used to calculate the ages used here for the fish teeth/debris data (Thomas et al., 2003).

\subsection{Sample preparation}

Freeze-dried sediment samples were obtained from the Integrated Ocean Drilling Program (IODP). One to two grams dry weight of sediment was then rinsed with ultra-high-purity (Milli-Q) water, and then processed following established sediment leaching protocols (e.g., Bayon et al., 2002, 2004; Haley et al., 2008a; Jacobsen and Wasserburg, 1979; Martin et al., 2010; Piotrowski et al., 2008; Rutberg et al., 2000; Scher and Martin, 2006). Briefly, we thoroughly rinse the sediments with Milli-Q water, leach with buffered acetic acid for $2.5 \mathrm{~h}$ and collect the leachate, and then rinse thoroughly with Milli-Q again before the reduction of early diagenetic metal oxide coatings that carry the bottom water $\mathrm{Nd}$ isotope signatures with a dilute buffered hydroxylamine.HCl-acetic acid solution. This buffered hydroxylamine. $\mathrm{HCl}$-acetic acid solution leaches the authigenic metal oxide coatings, which are then removed from the sediment and run through standard chromatographic procedures to extract a pure $\mathrm{Nd}$ solution for mass spectrometric analyses (AG 50W X12 resin for cation separation followed by di-2-ethylexyl-phosphate resin for rare earth element separation; see Gutjahr et al., 2007, for details). The reliability of these signatures is supported by recent publications demonstrating the validity of hydroxylamine. $\mathrm{HCl}$ leaches in the absence of volcanic material (e.g., Khélifi and Frank, 2014; Böhm et al., 2015). Potential uncertainties are associated with leaching sediments that may have undergone late stage diagenesis, although to our knowledge no particular examples exist in the literature for the influence of late stage diagenesis on the recorded $\varepsilon_{\mathrm{Nd}}$ signature. For this reason we focus our interpretations on the relative changes in the $\mathrm{Nd}$ isotope signature rather than on absolute values.

\subsection{Sample analysis}

Nd was analyzed on two instruments: a Triton thermalionization mass spectrometer at IFM-GEOMAR, using ${ }^{146} \mathrm{Nd} /{ }^{144} \mathrm{Nd}=0.7219$ to correct for instrument fractionation, and a $\mathrm{Nu}$ Instruments multi-collector inductively coupled mass spectrometer at Oregon State University. Nd isotopes are expressed in $\varepsilon_{\mathrm{Nd}}$ notation, defined as the deviation of measured ${ }^{143} \mathrm{Nd} /{ }^{144} \mathrm{Nd}$ ratios from a bulk Earth value of CHUR (chondritic uniform reservoir) in the fifth decimal place (Thomas et al., 2003). Long-term reproducibility of a Nd standard solution (SPEX source) gave a $2 \sigma$ error of $0.5 \varepsilon_{\mathrm{Nd}}$ units representing the total error of analyses and normalization, exactly like the samples. Analyses of the JNdi standard used for normalization had a lower $2 \sigma$ error of $0.3 \varepsilon_{\mathrm{Nd}}$ units. $\mathrm{Nd}$ isotope data are not corrected for decay of samarium given the limited temporal range of the data and the lack of constraints on sample $\mathrm{Sm} / \mathrm{Nd}$ isotope ratios. Nd isotope corrections for the PETM are typically small ( $<0.5 \varepsilon_{\mathrm{Nd}}$ units; Thomas et al., 2003) and therefore do not influence our interpretations. 


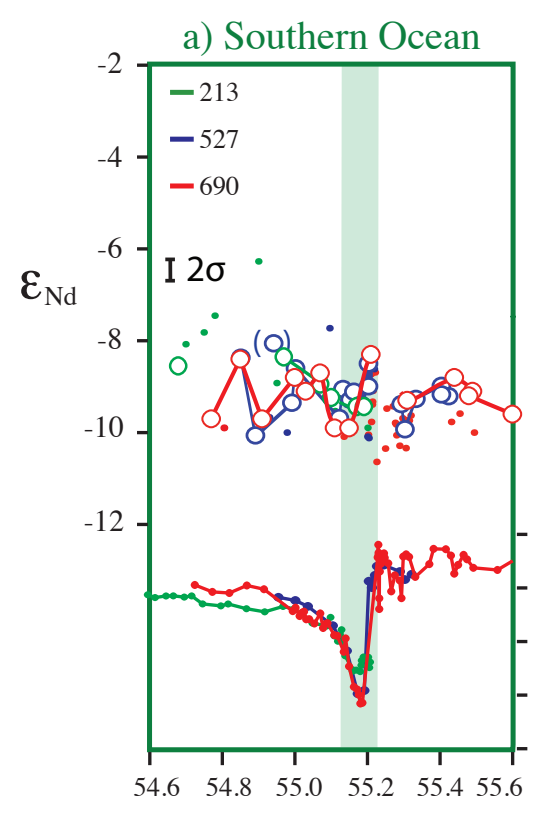

Age (Ma) b) Pacific Ocean

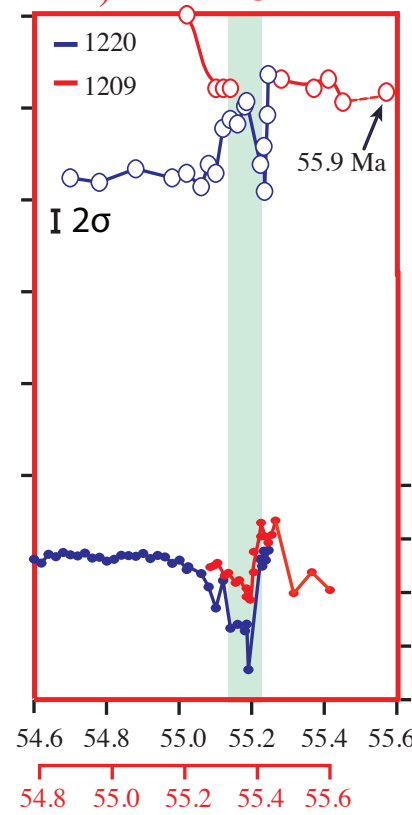

Age (Ma) c) Atlantic Ocean

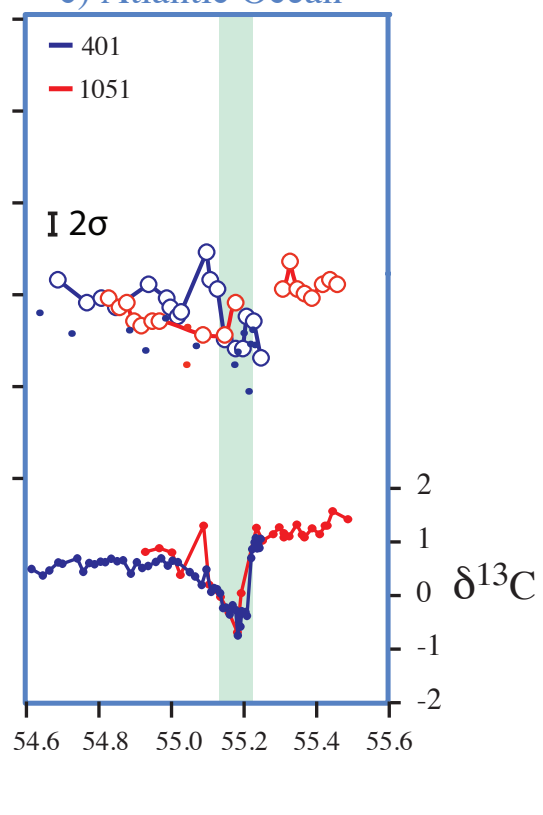

Age (Ma)

Figure 1. $\mathrm{Nd}$ and $\mathrm{C}$ isotope data $\left(\varepsilon_{\mathrm{Nd}}\right.$ and $\left.\delta^{13} \mathrm{C}\right)$ across the PETM from the Southern Ocean (a), Pacific Ocean (b), and Atlantic Ocean (c). The sediment leach $\varepsilon_{\mathrm{Nd}}$ are shown with circles and solid lines; the fish teeth/debris $\varepsilon_{\mathrm{Nd}}$ from Thomas et al. (2003) are shown as dots. All data are presented on directly comparable scales for both $\varepsilon_{\mathrm{Nd}}$ and $\delta^{13} \mathrm{C}$. The sample ages are based on the $\delta^{13} \mathrm{C}$ age models. In $(\mathbf{b})$ the age model of Site 1209B has been slightly adjusted (second $x$ axis) such that the $\delta^{13} \mathrm{C}$ excursion coincides with the age of the PETM in the other cores. The shaded vertical bar indicates the timing of the PETM as defined by the CIE in the cores.

\section{Results and discussion}

We have applied a leaching technique (Gutjahr et al., 2007; Haley et al., 2008a, b; Rutberg et al., 2000) that allows the extraction of past bottom water $\mathrm{Nd}$ isotope compositions from the $\mathrm{Fe}-\mathrm{Mn}$ oxide component of marine sediments, expressed as $\varepsilon_{\mathrm{Nd}}$ units (Jacobsen and Wasserburg, 1979). Such data provide high-resolution records of changes in past deep-water mass mixing and are used to reconstruct deep-ocean circulation (Böhm et al., 2015; Martin et al., 2010, 2012; Piotrowski et al., 2004, 2005, 2008; Thomas et al., 2014). Here we compare deep-water $\mathrm{Nd}$ isotope data obtained from leachates to fish teeth records and carbon isotope data from the same cores, which allows us to elucidate the causes and controls of $\delta^{13} \mathrm{C}$ variations in the past deep oceans (Piotrowski et al., 2005). Our new Nd isotope data are combined with existing $\delta^{13} \mathrm{C}$ records and published $\mathrm{Nd}$ isotope data from fossil fish teeth of the Atlantic, Indian, and Southern oceans (Thomas et al., 2003) in order to obtain a reconstruction of $\mathrm{Nd}$ isotope distributions, and thus deep-ocean circulation, for all major ocean basins across the PETM at a resolution comparable to the corresponding $\delta^{13} \mathrm{C}$ data (Fig. 1, Table 3).

\subsection{Comparison of neodymium isotope data obtained using different archives}

Consistent with published results for a number of different sedimentary environments (Martin et al., 2012), we find a general agreement (Fig. 1) between Nd isotopic data from sediment leaches and fish teeth (Thomas et al., 2003): there does appear to be a small systematic offset between these data at sites 401 and 690B. This offset may be the result of a temporal difference between uptake or retention of $\mathrm{Nd}$ in teeth and the ferromanganese coatings during sedimentation and diagenesis, of higher-order variability at these locations, or a combination of the two. Regarding the latter of these, model studies (Lunt et al., 2011; Winguth et al., 2010) have confirmed that locations near the Antarctic continent, such as at Site 690B, were sensitive to changes in climate conditions and, as such, likely to have varied more substantially during the PETM (55.14-55.23 Ma for this study based on the CIE; Fig. 1). Due to limited constraints to explain the offsets between fish teeth and leach records in detail, we focus our interpretations on the relative trends and broader patterns of the $\varepsilon_{\mathrm{Nd}}$ signatures over time and their relation to the CIE rather than on absolute values. 
Table 3. Summary of neodymium isotope data. Sample description and $\varepsilon_{\mathrm{Nd}}$.

\begin{tabular}{|c|c|c|c|c|c|}
\hline \multirow[t]{2}{*}{ Hole } & \multirow[t]{2}{*}{ Core section } & \multicolumn{2}{|c|}{ Depth interval $(\mathrm{cm})$} & \multirow[t]{2}{*}{$\varepsilon_{\mathrm{Nd}}$} & \multirow[t]{2}{*}{ Age Ma } \\
\hline & & Upper & Lower & & \\
\hline 1220B & $20 \mathrm{X}-1$ & 65 & 67 & -5.70 & 54.70 \\
\hline $1220 \mathrm{~B}$ & $20 \mathrm{X}-1$ & 85 & 87 & -5.80 & 54.78 \\
\hline 1220B & $20 \mathrm{X}-1$ & 110 & 112 & -5.50 & 54.88 \\
\hline 1220B & $20 \mathrm{X}-1$ & 135 & 137 & -5.70 & 54.98 \\
\hline 1220B & $20 \mathrm{X}-1$ & 145 & 147 & -5.60 & 55.02 \\
\hline 1220B & $20 X-2$ & 5 & 7 & -5.90 & 55.06 \\
\hline 1220B & $20 X-2$ & 10 & 12 & -5.40 & 55.08 \\
\hline 1220B & $20 X-2$ & 15 & 17 & -5.60 & 55.10 \\
\hline 1220B & $20 X-2$ & 20 & 22 & -4.60 & 55.12 \\
\hline 1220B & $20 X-2$ & 25 & 27 & -4.40 & 55.14 \\
\hline 1220B & $20 \mathrm{X}-2$ & 30 & 32 & -4.50 & 55.16 \\
\hline 1220B & $20 X-2$ & 35 & 37 & -4.10 & 55.18 \\
\hline 1220B & $20 \mathrm{X}-2$ & 40 & 42 & -4.00 & 55.19 \\
\hline 1220B & $20 X-2$ & 80 & 82 & -5.40 & 55.22 \\
\hline $1220 \mathrm{~B}$ & $20 X-2$ & 90 & 92 & -5.00 & 55.23 \\
\hline 1220B & $20 \mathrm{X}-2$ & 93 & 94 & -6.00 & 55.24 \\
\hline $1220 \mathrm{~B}$ & 20X-CCW & 5 & 6 & -4.31 & 55.24 \\
\hline 1220B & 20X-CCW & 6 & 7 & -3.41 & 55.25 \\
\hline 1209B & $22 \mathrm{H}-1$ & 12 & 14 & -2.10 & 55.02 \\
\hline 1209B & $22 \mathrm{H}-1$ & 39 & 40 & -3.68 & 55.10 \\
\hline 1209B & $22 \mathrm{H}-1$ & 47 & 48 & -3.71 & 55.13 \\
\hline 1209B & $22 \mathrm{H}-1$ & 48 & 49 & -3.69 & 55.14 \\
\hline 1209B & 22R-1 & 84 & 86 & -3.50 & 55.28 \\
\hline 1209B & $22 \mathrm{R}-1$ & 108 & 110 & -3.70 & 55.37 \\
\hline 1209B & 22R-1 & 120 & 122 & -3.50 & 55.41 \\
\hline 1209B & 22R-1 & 132 & 134 & -4.00 & 55.45 \\
\hline 1209B & 22R-1 & 148 & 150 & -3.70 & 55.85 \\
\hline 0690B & $18 \mathrm{H}-5$ & 36 & 37 & -9.70 & 54.77 \\
\hline 0690B & $18 \mathrm{H}-6$ & 30 & 31 & -8.40 & 54.84 \\
\hline 0690B & $18 \mathrm{H}-6$ & 110 & 111 & -9.70 & 54.91 \\
\hline 0690B & $19 \mathrm{H}-1$ & 30 & 31 & -8.80 & 55.00 \\
\hline 0690B & $19 \mathrm{H}-1$ & 65 & 66 & -9.10 & 55.03 \\
\hline 0690B & $19 \mathrm{H}-1$ & 137 & 138 & -8.70 & 55.07 \\
\hline 0690B & $19 \mathrm{H}-2$ & 47 & 48 & -9.90 & 55.11 \\
\hline 0690B & $19 \mathrm{H}-2$ & 109 & 110 & -9.90 & 55.15 \\
\hline 0690B & $19 \mathrm{H}-3$ & 69 & 71 & -8.30 & 55.21 \\
\hline 0690B & $19 \mathrm{H}-4$ & 66 & 67 & -9.30 & 55.31 \\
\hline 0690B & $19 \mathrm{H}-5$ & 6 & 7 & -8.80 & 55.36 \\
\hline 0690B & $19 \mathrm{H}-5$ & 65 & 66 & -9.10 & 55.44 \\
\hline 0690B & $19 \mathrm{H}-5$ & 106 & 107 & -9.20 & 55.48 \\
\hline 0690B & $20 \mathrm{H}-1$ & 3 & 4 & -9.63 & 55.53 \\
\hline 0690B & $20 \mathrm{H}-1$ & 140 & 141 & -9.84 & 55.80 \\
\hline 0690B & $20 \mathrm{H}-2$ & 111 & 112 & -9.20 & 56.17 \\
\hline 527 & 24R-1 & 11 & 12 & -8.27 & 54.85 \\
\hline 527 & $24 \mathrm{R}-1$ & 31 & 32 & -9.98 & 54.89 \\
\hline 527 & $24 \mathrm{R}-1$ & 53 & 54 & -7.95 & 54.94 \\
\hline 527 & $24 \mathrm{R}-1$ & 81 & 82 & -9.26 & 54.99 \\
\hline 527 & $24 \mathrm{R}-1$ & 100 & 102 & -8.50 & 55.00 \\
\hline 527 & 24R-1 & 140 & 142 & -9.60 & 55.12 \\
\hline 527 & $24 \mathrm{R}-2$ & 11 & 12 & -8.96 & 55.13 \\
\hline 527 & $24 \mathrm{R}-2$ & 41 & 42 & -9.20 & 55.15 \\
\hline
\end{tabular}

Table 3. Continued.

\begin{tabular}{|c|c|c|c|c|c|}
\hline \multirow[t]{2}{*}{ Hole } & \multirow[t]{2}{*}{ Core section } & \multicolumn{2}{|c|}{ Depth interval $(\mathrm{cm})$} & \multirow[t]{2}{*}{$\varepsilon_{\mathrm{Nd}}$} & \multirow[t]{2}{*}{ Age Ma } \\
\hline & & Upper & Lower & & \\
\hline 527 & $24 \mathrm{R}-2$ & 87 & 88 & -9.02 & 55.16 \\
\hline 527 & $24 \mathrm{R}-2$ & 24 & 27 & -9.30 & 55.18 \\
\hline 527 & $24 \mathrm{R}-2$ & 30 & 33 & -8.90 & 55.20 \\
\hline 527 & $24 \mathrm{R}-2$ & 47 & 48 & -8.40 & 55.20 \\
\hline 527 & $24 \mathrm{R}-3$ & 59 & 60 & -9.29 & 55.29 \\
\hline 527 & $24 \mathrm{R}-3$ & 81 & 82 & -9.85 & 55.30 \\
\hline 527 & $24 \mathrm{R}-3$ & 121 & 122 & -9.18 & 55.33 \\
\hline 527 & $24 \mathrm{R}-4$ & 10 & 11 & -8.89 & 55.40 \\
\hline 527 & $24 \mathrm{R}-4$ & 40 & 41 & -9.12 & 55.42 \\
\hline 527 & $24 \mathrm{R}-4$ & 80 & 81 & -9.08 & 55.40 \\
\hline 213 & $16-3$ & 48 & 49 & -8.60 & 54.69 \\
\hline 213 & $16-4$ & 8 & 9 & -8.40 & 54.97 \\
\hline 213 & $16-4$ & 49 & 50 & -9.00 & 55.08 \\
\hline 213 & $16-4$ & 58 & 59 & -9.30 & 55.10 \\
\hline 213 & $16-4$ & 90 & 91 & -9.50 & 55.17 \\
\hline 213 & $16-4$ & 99 & 100 & -9.50 & 55.19 \\
\hline 1051B & $59 X-2$ & 110 & 111 & -8.23 & 54.50 \\
\hline 1051B & $59 X-2$ & 139 & 140 & -8.41 & 54.60 \\
\hline 1051B & $59 X-3$ & 26 & 27 & -8.26 & 54.76 \\
\hline 1051B & $59 X-3$ & 46 & 47 & -8.65 & 54.80 \\
\hline 1051B & $59 X-3$ & 67 & 68 & -8.81 & 54.90 \\
\hline 1051B & $59 X-3$ & 87 & 88 & -8.75 & 54.94 \\
\hline 1051B & $59 X-3$ & 120 & 120 & -8.70 & 54.97 \\
\hline 1051B & $60 X-1$ & 65 & 65 & -9.00 & 55.09 \\
\hline $1051 \mathrm{~B}$ & $60 X-1$ & 119 & 120 & -9.00 & 55.15 \\
\hline 1051B & $60 X-1$ & 145 & 145 & -8.30 & 55.18 \\
\hline 1051B & $60 X-2$ & 56 & 56 & -8.00 & 55.31 \\
\hline 1051B & $60 X-2$ & 64 & 66 & -7.40 & 55.33 \\
\hline 1051B & $60 X-2$ & 74 & 75 & -8.00 & 55.35 \\
\hline 1051B & $60 X-2$ & 84 & 85 & -8.05 & 55.37 \\
\hline 1051B & $60 X-2$ & 93 & 94 & -8.20 & 55.39 \\
\hline 1051B & $60 X-2$ & 109 & 110 & -7.89 & 55.42 \\
\hline 1051B & $60 X-2$ & 118 & 119 & -7.79 & 55.44 \\
\hline 1051B & $60 X-2$ & 142 & 143 & -7.93 & 55.52 \\
\hline 401 & $14 \mathrm{R}-1$ & 45 & 47 & -7.80 & 54.69 \\
\hline 401 & $14 \mathrm{R}-1$ & 100 & 101 & -8.26 & 54.77 \\
\hline 401 & $14 \mathrm{R}-1$ & 125 & 126 & -8.24 & 54.81 \\
\hline 401 & $14 \mathrm{R}-1$ & 146 & 147 & -8.40 & 54.85 \\
\hline 401 & $14 \mathrm{R}-2$ & 50 & 52 & -7.90 & 54.94 \\
\hline 401 & $14 \mathrm{R}-2$ & 83 & 85 & -8.20 & 54.99 \\
\hline 401 & $14 \mathrm{R}-2$ & 91 & 93 & -8.40 & 55.00 \\
\hline 401 & $14 \mathrm{R}-2$ & 100 & 102 & -8.60 & 55.02 \\
\hline 401 & $14 \mathrm{R}-2$ & 110 & 112 & -8.50 & 55.03 \\
\hline 401 & $14 \mathrm{R}-2$ & 148 & 150 & -7.20 & 55.10 \\
\hline 401 & $14 \mathrm{R}-3$ & 6 & 8 & -7.80 & 55.11 \\
\hline 401 & $14 \mathrm{R}-3$ & 21 & 23 & -8.00 & 55.13 \\
\hline 401 & $14 \mathrm{R}-3$ & 31 & 33 & -9.10 & 55.15 \\
\hline 401 & $14 \mathrm{R}-3$ & 52 & 54 & -9.30 & 55.18 \\
\hline 401 & $14 \mathrm{R}-3$ & 84 & 86 & -9.30 & 55.20 \\
\hline 401 & $14 \mathrm{R}-3$ & 90 & 92 & -8.60 & 55.21 \\
\hline 401 & $14 \mathrm{R}-3$ & 122 & 124 & -8.70 & 55.23 \\
\hline 401 & $14 \mathrm{R}-3$ & 148 & 150 & -9.50 & 55.25 \\
\hline
\end{tabular}




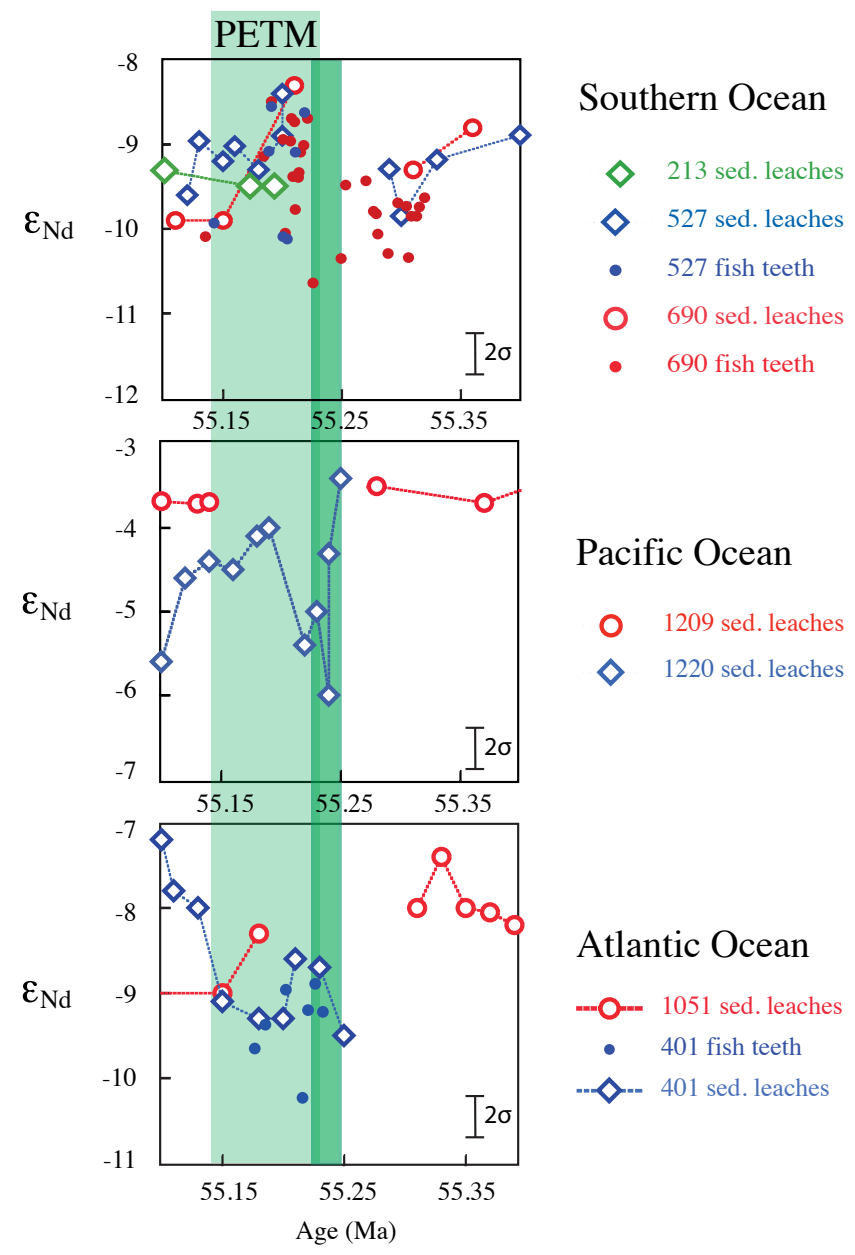

Figure 2. Sediment leach $\varepsilon_{\mathrm{Nd}}$ and available fish teeth $\varepsilon_{\mathrm{Nd}}$ data from 55.1 to $55.4 \mathrm{Ma}$ for all three ocean basins. Sediment $\varepsilon_{\mathrm{Nd}}$ values are connected with a dotted line and fish teeth data are represented by unconnected dots. The light-green shaded area represents the PETM as defined by the carbon isotope excursion from each core. The dark-green shaded area reflects our interpretation of the "trigger" timing.

\subsection{Basin-wide changes in deep-water $\mathrm{Nd}$ isotope compositions}

The overall patterns in our records support previous studies that have inferred convection patterns in the Southern Ocean and in both the North and South Pacific during the PETM. Our $\varepsilon_{\mathrm{Nd}}$ records cover the three major ocean basins (Fig. 1) and reveal distinct and basin-specific changes in deep circulation across the PETM. These data suggest that a change in ocean circulation may have triggered the carbon release associated with the PETM; in particular Pacific Site 1220 is key in that it shows variance of up to $\sim 2 \varepsilon_{\mathrm{Nd}}$ units prior to the CIE (Fig. 2), while fish teeth $\varepsilon_{\mathrm{Nd}}$ records indicate a similarly sized excursion in the Southern Ocean.

Southern Ocean sites 527 (subtropical South Atlantic) and 690 (Atlantic sector of the Southern Ocean) fluctuated (1 to
$1.3 \varepsilon_{\mathrm{Nd}}$ units) around a mean $\varepsilon_{\mathrm{Nd}}$ signature of $\sim-9$ throughout the record, with indications of a shift to in-phase covariation during and after the PETM, also reflected by the evolution of Site 213 (Fig. 1). The $\varepsilon_{\mathrm{Nd}}$ records for eastern North Atlantic Site 401 stabilize at $\sim-9.3$ during the PETM and then at $\sim-8.2$ post-PETM, with the trend towards more radiogenic values occurring at the end of the PETM. While the fish teeth $\varepsilon_{\mathrm{Nd}}$ record is not a step function, the observed magnitude and direction of change in leachate $\varepsilon_{\mathrm{Nd}}$ signatures is consistent with those changes reported from fish teeth $\varepsilon_{\mathrm{Nd}}$ signatures (Thomas et al., 2003) (Figs. 1, 2). Deep waters at central (western) Atlantic Site 1051B, located near the protoCaribbean, had a more positive $\varepsilon_{\mathrm{Nd}}(\sim-8)$ than Site 401 prior to the PETM, but post-PETM $\varepsilon_{\mathrm{Nd}}$ signatures at both sites converged (Fig. 1). The record of Site 1051B exhibits similarities to post-PETM data from Site 401, which could indicate greater mixing within the North Atlantic following PETM recovery (Fig. 1). Pacific sites 1209B and 1220B were more radiogenic than the other basins $\left(\varepsilon_{\mathrm{Nd}}\right.$ from -6 to -2$)$. With the exception of one data point $\left(-2.1 \varepsilon_{\mathrm{Nd}}\right.$ at 55.02 Ma), the western Pacific (Site 1209B) had a remarkably constant $\varepsilon_{\mathrm{Nd}}$ signature of -3.7 pre- and post-PETM (Fig. 1). In contrast, the eastern Pacific (Site 1220B) $\varepsilon_{\mathrm{Nd}}$ shows variance from $\sim-4$ to $\sim-5.5 \varepsilon_{\mathrm{Nd}}$ prior to and during the PETM, before stabilizing after the PETM at $\varepsilon_{\mathrm{Nd}}$ of $\sim-5$ (Figs. 1, 2).

\subsection{A conceptual model to explain the records}

The dissimilarities between the $\varepsilon_{\mathrm{Nd}}$ records confirm that the globally consistent CIE dominantly reflects a change in the source of oceanic carbon (Thomas et al., 2002). This change is not directly from a volcanic or extraterrestrial source, as these would also be seen in the $\varepsilon_{\mathrm{Nd}}$ records (Cramer and Kent, 2005). However, the $\varepsilon_{\mathrm{Nd}}$ data also clearly indicate that changes in water mass distributions and mixing were associated with the PETM and suggest a fundamentally different circulation patterns existed during this period of time. Without such changes in circulation, we would expect the $\varepsilon_{\mathrm{Nd}}$ signals to remain constant over the entire record or only show a slow and predictable trend that reflects changes on geological timescales (e.g., the evolution of weathering inputs as opposed to more rapid oceanic changes). Figure 3 illustrates our hypothetical reconstruction of the evolution of global deep-water mass exchange during the PETM, based on the interpretation of the global ocean as three distinct deep-water basins: the Southern Ocean, the North Atlantic, and the Pacific. While in this model we hypothesize the basins only had restricted water mass exchange between them, we cannot eliminate the possibility of unrestricted exchange since similar-scale inter-basinal differences in $\varepsilon_{\mathrm{Nd}}$ are observed in the modern ocean without this restriction. That is, the modern North Atlantic Deep Water signature increases by $\sim 1.5 \varepsilon_{\mathrm{Nd}}$ unit from the North $\left(-13.5 \varepsilon_{\mathrm{Nd}}\right)$ to South Atlantic $\left(-12 \varepsilon_{\mathrm{Nd}}\right.$; 


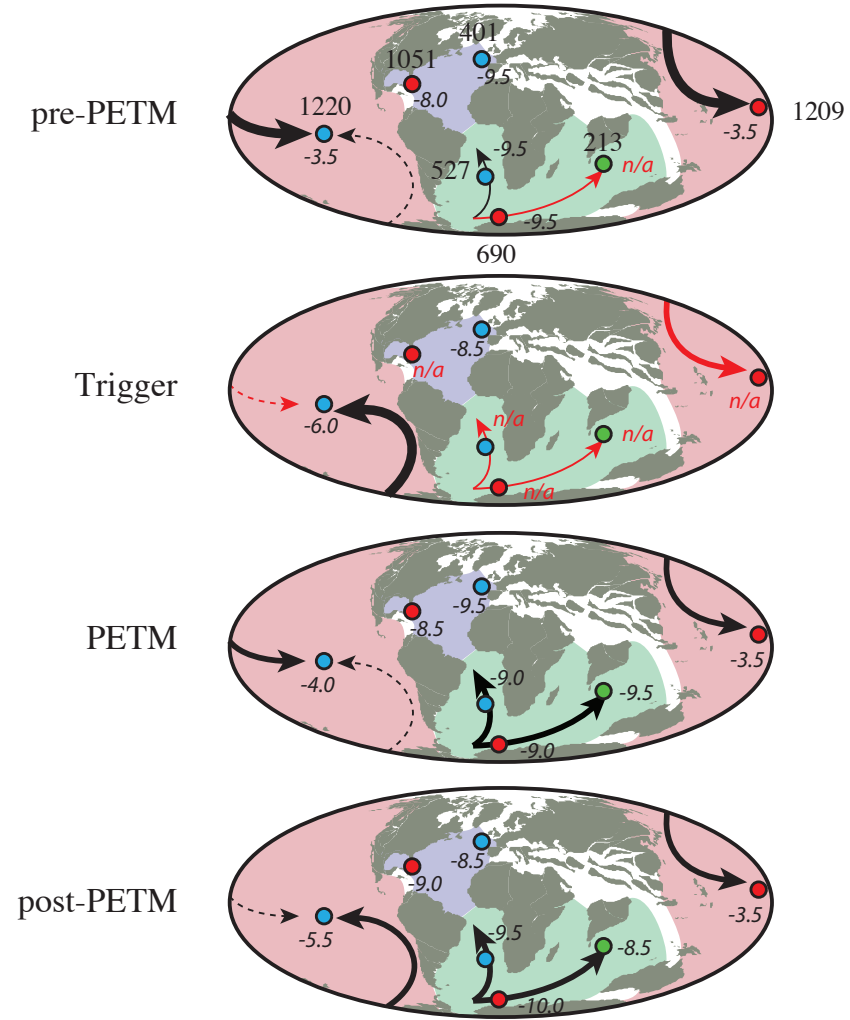

Figure 3. A conceptual model of the intermediate/deep-water mixing changes across the PETM as inferred from $\varepsilon_{\mathrm{Nd}}$ records of intermediate/deep-water mass geometries. Arrow boldness reflects overturning circulation that could produce water mass geometries. Dashed arrows represent weak overturning. Italicized numbers indicate an $\varepsilon_{\mathrm{Nd}}$ estimate interpreted from each site for the time period. The time periods are broadly divided into a pre-PETM period, including all data prior to the "trigger" as denoted in Fig. 2; the "trigger" period which slightly precedes and overlaps with the PETM; the PETM as defined by the CIE; and the post-PETM, including all data after the CIE. Red arrows indicate interpretations that are more speculative as the data are not available. The arrow directions reflect our interpretation of the general direction of flow, and are not meant to be viewed as precise flow paths. The paleogeographic distribution of the continents is from Ocean Drilling Stratigraphic Network (ODSN).

Lacan et al., 2012) due to mixing, which is a similar magnitude to the offset observed in our data $\left(\sim 1 \varepsilon_{\mathrm{Nd}}\right.$ unit).

Our interpretation of these $\delta^{13} \mathrm{C}$ and $\varepsilon_{\mathrm{Nd}}$ data supports changes in areas of convection that are consistent with simulations of the PETM with coupled climate models (Lunt et al., 2012; Thomas et al., 2014) and with a comprehensive climate model (Winguth et al., 2010). It is impossible to interpret from the $\mathrm{Nd}$ isotope data alone whether there was reduced or increased overturning associated with carbon release, as these data reflect water mass geometries and not rates of overturning. It is of note that model simulations support a weakening of the meridional overturning circulation with increased greenhouse gases, which might result in a water mass geometry similar to what is reconstructed. However, changes in the exchange between ocean basins will be dependent on several factors, including buoyancy-induced and wind-stress induced changes in overturning, as well as topography. Below we discuss whether there is evidence for changes in ventilation from basinal deep-water aging gradients, and what the nature of topographic barriers may have been to produce the observed patterns in the data.

\subsubsection{Southern Ocean records}

An $\varepsilon_{\mathrm{Nd}}$ signature of -9.2 in the Southern Ocean most likely reflects an Antarctic margin source, similar to present-day Antarctic-sourced intermediate waters (Stichel et al., 2012; Thomas et al., 2003). In agreement with previous inferences from $\delta^{13} \mathrm{C}$ data (Tripati and Elderfield, 2005; Zeebe and Zachos, 2007), such a deep-water source can readily explain the post-PETM similarity of the $\varepsilon_{\mathrm{Nd}}$ records from both the Southern Atlantic (Site 527) and Indian Ocean (Site 213) with the Atlantic sector of the Southern Ocean (Site 690) (Figs. 1, 3). There are indications that the covariation of $\varepsilon_{\mathrm{Nd}}$ at sites 213, 527, and 690 was enhanced immediately before, during, and following the PETM, which is consistent with an intensification of Southern Ocean-sourced ventilation (Figs. 1, 2a) that systematically affected all sites.

The $\varepsilon_{\mathrm{Nd}}$ signatures from fish teeth from sites 690 and 527 suggest rapid changes in circulation leading into and during the early part of the PETM (Fig. 2). The previously proposed formation of low-latitude Tethyan deep water (e.g., Cope and Winguth, 2011; Huber and Sloan, 2001) or slower overturning circulation (Winguth et al., 2010) is unlikely to have generated such a range and similarity in the evolution of $\varepsilon_{\mathrm{Nd}}$ signatures at these three sites. Furthermore, numerical simulations indicate that strong overturning circulation with multiple deep convection sites best explains the $\varepsilon_{\mathrm{Nd}}$ record (Thomas et al., 2014).

\subsubsection{Atlantic Ocean records}

The contrast in $\varepsilon_{\mathrm{Nd}}$ trends between the Southern Ocean and those of the North Atlantic (Figs. 1 and 2) indicates that there was little exchange between these basins. The young MidAtlantic Ridge (MAR) between Africa and South America most likely represented an efficient barrier for north-south intermediate and deep-water exchange (Bice and Marotzke, 2002). This differs from previous interpretations of overturning circulation in the Atlantic (Bice and Marotzke, 2002; Nunes and Norriz, 2006; Thomas et al., 2003), but confirms recent modeling results (Winguth et al., 2010). The differences between the two North Atlantic $\varepsilon_{\mathrm{Nd}}$ records can be readily explained by a weak North Atlantic deep-water overturning cell, resulting in higher sensitivity to local changes in $\mathrm{Nd}$ inputs or locally variable deep-water mass circulation. Assuming weak, low-latitude, halothermally driven down- 
welling in the North Atlantic basin, we would expect Site 401 to show an $\varepsilon_{\mathrm{Nd}}$ evolution different from Site 1051B, which is indeed documented in Fig. 2c. The contrasting North Atlantic $\varepsilon_{\mathrm{Nd}}$ records (Fig. 2c) also support model predictions (Winguth et al., 2010) that the North Atlantic was well stratified until after the PETM, which is reflected by the later convergence of the $\mathrm{Nd}$ isotope records indicating more efficient vertical and basinal mixing (Fig. 1). Pre-PETM stratification was potentially interrupted briefly near the onset of the PETM. Specifically, $\varepsilon_{\mathrm{Nd}}$ signatures of fish teeth from Site 401 indicate that the Atlantic may have experienced rapid circulation change early in the PETM (Fig. 2c) with $\varepsilon_{\mathrm{Nd}}$ briefly shifting from $\sim-9$ to $\sim-10$.

\subsubsection{Pacific Ocean records}

The distinct $\varepsilon_{\mathrm{Nd}}$ records of the Pacific point to restricted Pacific intermediate water mass exchange with the Southern Ocean (Fig. 3). A possible barrier preventing substantial exchange between the Southern Ocean and Pacific Ocean was the shallow seas between southern Asia and Australia (Bice and Marotzke, 2002). Within the Pacific Ocean, times of convergent $\varepsilon_{\mathrm{Nd}}$ can be explained by a weakened southern Pacific ventilation which would allow northern Pacific water to influence both sites. Conversely, with intensified Southern Oceansourced ventilation, the $\varepsilon_{\mathrm{Nd}}$ signature of deep waters at Pacific Site 1220B would have diverged from the signatures of the northern source (Bice and Marotzke, 2002).

It follows that a Pacific circulation pattern consistent with both $\delta^{13} \mathrm{C}$ and $\varepsilon_{\mathrm{Nd}}$ data must involve distinct southern and northern Pacific sources of deep waters, as predicted in previous studies (Lunt et al., 2011; Thomas, 2004; Thomas et al., 2008; Winguth et al., 2010). While we unfortunately lack samples prior to $55.25 \mathrm{Ma}$, there is high variability in the $\varepsilon_{\mathrm{Nd}}$ record at Site 1220 immediately prior to and at the beginning of the PETM (based on the CIE timing) that may reflect sudden and short-lived intensification in deep-water formation in the North Pacific (Fig. 2, 3). The initial change in $\varepsilon_{\mathrm{Nd}}$ from $\sim-4$ to $\sim-6$ at Site 1220 B clearly occurred stratigraphically below the negative CIE, consistent with the hypothesis that circulation changes triggered PETM carbon release.

Alternative scenarios are that the more negative $\varepsilon_{\mathrm{Nd}}$ at the beginning of the PETM reflects a dramatic change in ventilation from a southern source that occurred just prior to the PETM, possibly accompanied by a change in deep-ocean redox conditions leading to diagenetic alteration of the $\mathrm{Nd}$ isotope record. However, several lines of evidence suggest the negative Nd isotope "excursion" at the start of the PETM reflects changes in bottom water sourcing and not changes in the position of a sediment redox front. First, a ventilation change in the deep Pacific is in agreement with interpretations of carbon isotope data that support a reversal or large change in deep-water aging gradients between basins (Tripati and Elderfield, 2005). Secondly, there are carbonate geochemical data that suggest a reversal or dramatic change in deep-ocean carbonate saturation gradients between basins, consistent with a major circulation change (Zeebe and Zachos, 2007). Thirdly, substantially larger redox changes are observed in PETM sequences from other basins (i.e., the South Atlantic; Chun et al., 2010) that do not exhibit similar corresponding shifts in records of $\varepsilon_{\mathrm{Nd}}$. Fourthly, similar types of changes are observed during Cretaceous ocean anoxic events (Martin et al., 2012) where there also is no unequivocal evidence for redox fronts biasing the sediment leachate $\varepsilon_{\mathrm{Nd}}$ record. Finally, core photographs show that transitions in sediment redox at Site 1220B are not directly coincident with the $\varepsilon_{\mathrm{Nd}}$ change.

Thus, we conclude our Nd isotope data are consistent with other proxy data (Nunes and Norris, 2006; Tripati and Elderfield, 2005; Zeebe and Zachos, 2007) and models (Bice and Marotske, 2002; Lunt et al, 2011) and reflect a circulation change at the PETM. These data indicate a Pacific circulation "trigger" for carbon release, the record of which is, as predictable, most pronounced in the Pacific Ocean. Some simulations indicate that at the PETM a change in state of a southern Pacific deep-water source may have contributed to hydrate destabilization, which these data may reflect; such changes in Southern Ocean water mass characteristics could ultimately have arisen from a gradual forcing such as volcanic outgassing (Kennett and Stott, 1991; Bice and Marotske, 2002; Lunt et al., 2011; Tripati and Elderfield, 2005).

One outstanding feature in our data is the mode of circulation during and after the PETM. As depicted in Fig. 3, our data suggest that the circulation pattern prior to the $\varepsilon_{\mathrm{Nd}}$ "excursion" was similar to that prevailing during the PETM. In contrast the "trigger" circulation mode (i.e., during the "excursion" itself) was similar to the mode of circulation after the PETM. While it is unfortunate that no additional samples are available from Site 1220B to further investigate these trends, we have confidence that they are representative of the changes that occurred given that more than one data point defines each part of the "excursion" (Fig. 2a). In essence, our interpretation simply implies that deep-ocean circulation in the Pacific switched between two modes during this period of time. That the $\varepsilon_{\mathrm{Nd}}$ data of sites 1220B and 1209 are similar prior to the "excursion" and that the $\varepsilon_{\mathrm{Nd}}$ of Site 1220B appears to be bimodal (at $\sim-5.5$ and $\sim-4.5$ ) is consistent with the idea of two distinct circulation patterns. The fact that the CIE was a transient pulse reflective of the source function of the carbon is not inconsistent with our interpretations presented here.

\section{Conclusions}

Our study provides new neodymium isotope data from $\mathrm{Fe}-$ Mn leachates constraining changes in ocean circulation associated with the PETM. The novelty of these Nd isotope data reflects advances in our ability to extract such data from 
pelagic sediments, which has opened new avenues of paleoceanographic research. Using Nd isotopes, a proxy independent of carbon cycle processes, we unravel oceanographic changes during the PETM and are able to isolate competing factors controlling the carbon-isotope record during the PETM. In general, we find these data are similar to results from fish teeth (a more widely used proxy), and discuss the combined high-resolution records for seven sites.

The high-resolution combined $\mathrm{Nd}$ isotope records provide further evidence for changes in thermohaline circulation associated with the PETM, as previously inferred from basinal carbon isotope gradients (Nunes and Norris, 2006; Tripati and Elderfield, 2005) and constraints on deep-water carbonate ion concentrations (Zeebe and Zachos, 2007). In addition, these new records provide additional constraints on the timing and the nature of changes in circulation. The records are consistent with variations in bottom water mass mixing in each basin associated with the PETM, with water mass distributions implying intermediate and deep-water circulation changes. We find that changes in deep-ocean circulation occurred during the Paleocene-Eocene, and that these circulation changes likely preceded the carbon release, based on $\varepsilon_{\mathrm{Nd}}$ shifts observed stratigraphically below the carbon isotope excursion. Together with modeling results (Bice and Marotzke, 2002; Lunt et al., 2011, 2012; Winguth et al., 2010) and $\mathrm{Mg} / \mathrm{Ca}$-based bottom water temperature estimates (Tripati and Elderfield, 2005), Nd isotope data provide further evidence for thermohaline changes that may have served as a "trigger" of carbon release.

Acknowledgements. Samples were provided by the Integrated Ocean Drilling Program. NSF grant 1147407 supported the contributions of A. N. Abbott. A. K. Tripati was supported by a NERC Fellowship, a Junior Research Fellowship from Magdalene College, and the UCLA Division of Physical Sciences, and thanks Alex Piotrowski for discussing this work and making some pilot measurements. C. Teschner, R. Stumpf, and J. Heinze are acknowledged for laboratory support and F. Hauff is thanked for technical support of the mass spectrometer at GEOMAR, Kiel. This work was also supported by the "Laboratoire d'Excellence" LabexMER (ANR-10-LABX-19) and co-funded by a grant from the French government under the program "Investissements d'Avenir". We thank Jerry Dickens and an anonymous reviewer for thoughtful comments, and André Paul for editorial handling.

Edited by: A. Paul

\section{References}

Alexander, K., Meissner, K. J., and Bralower, T. J.: Sudden spreading of corrosive bottom water during the Palaeocene-Eocene Thermal Maximum, Nat. Geosci., 8, 458-462, 2015.

Bayon, G., German, C., Boella, R., Milton, J., Taylor, R., and Nesbitt, R.: An improved method for extracting marine sedi- ment fractions and its application to $\mathrm{Sr}$ and $\mathrm{Nd}$ isotopic analysis, Geochim. Cosmochim. Ac., 187, 170-199, 2002.

Bayon, G., German, C. R., Burton, K. W., Nesbitt, R. W., and Rogers, N.: Sedimentary Fe-Mn oxyhydroxides as paleoceanographic archives and the role of Aeolian flux in regulating oceanic dissolved REE, Earth Planet. Sc. Lett., 224, 477-492, doi:10.1016/j.eps1.2004.05.033, 2004.

Bice, K. L. and Marotzke, J.: Could changing ocean circulation have destabilized methane hydrate at the Paleocene/Eocene boundary?,Paleoceanography, 17, 1018, doi:10.1029/2001pa000678, 2002.

Böhm, E., Lippold, J., Gutjahr, M., Frank, M., Blaser, P., Antz, B., Fohlmeister, J., Frank, N., Andersen, M. B., and Deininger, M.: Strong and deep Atlantic meridional overturning circulation during the last glacial cycle, Nature, 517, 73-76, doi:10.1038/nature14059, 2015.

Bowen, G. J., Koch, P. L., Gingerich, P. D., Norris, R. D., Bains, S., and Corfield, R. M.: Refined isotope stratigraphy across the continental Paleocene-Eocene boundary on Polecat Bench in the northern Bighorn Basin, Paleocene-Eocene stratigraphy and biotic change in the Bighorn and Clarks Fork basins, Wyoming, University of Michigan Papers on Paleontology, 33, 73-88, 2001.

Bowen, G. J., Beerling, D. J., Koch, P. L., Zachos, J. C., and Quattlebaum, T.: A humid climate state during the Palaeocene/Eocene thermal maximum, Nature, 432, 495-499, 2004.

Chun, C. O., Delaney, M. L., and Zachos, J. C.: Paleoredox changes across the Paleocene-Eocene thermal maximum, Walvis Ridge (ODP Sites 1262, 1263, and 1266): Evidence from Mn and U enrichment factors, Paleoceanography, 25, PA4202, doi:10.1029/2009PA001861, 2010.

Cope, J. T. and Winguth, A.: On the sensitivity of ocean circulation to arctic freshwater input during the Paleocene/Eocene Thermal Maximum, Palaeogeogr. Palaeocl., 306, 82-94, 2011.

Cramer, B. S. and Kent, D. V.: Bolide summer: The Paleocene/Eocene thermal maximum as a response to an extraterrestrial trigger, Palaeogeogr. Palaeocl., 224, 144-166, doi:10.1016/j.palaeo.2005.03.040, 2005.

Dickens, G. R.: Methane oxidation during the late Paleocene thermal maximum, Bulletin de la Société Géologique de France, 171, 37-49, 2000.

Dickens, G. R., O’Niel, J. R., Rea, D. K., and Owen, R. M.: Dissociation of oceanic methane hydrate as a cause of the carbon isotope excursion at the end of the Paleocene, Paleoceanography, 10, 965-971, 1995.

Farley, K. A. and Eltgroth, S. F.: An alternative age model for the Paleocene-Eocene thermal maximum using extraterrestrial ${ }^{3} \mathrm{He}$, Earth Planet. Sc. Lett., 208, 135-148, 2003.

Frank, M.: Radiogenic isotopes: Tracers of part ocean circulation and erosional input, Rev. Geophys., 40, 1001, doi:10.1029/2000RG000094, 2002.

Goldstein, S. L., Hemming, S. R., Heinrich, D. H., and Karl, K. T.: Long-lived Isotopic Tracers, in: Oceanography, Paleoceanography, and Ice-sheet Dynamics, Treatise on Geochemistry, edited by: Elderfield, H., 453-489, 2003.

Gutjahr, M., Frank, M., Stirling, C.H., Klemm, V., van de Flierdt, T., and Halliday, A. N.: Reliable extraction of a deepwater trace metal isotope signal from Fe-Mn oxyhydroxide coatings of marine sediments, Chem. Geol., 242, 351-370, doi:10.1016/j.chemgeo.2007.03.021, 2007. 
Haley, B. A., Frank, M., Spielhagen, R. F., and Fietzke, J.:, Radiogenic isotope record of Arctic Ocean circulation and weathering inputs of the past 15 million years, Paleoceanography, 23, PA1S13, doi:10.1029/2007PA001486, 2008a.

Haley, B. A., Frank, M., Spielhagen, R. F., and Eisenhauer, A.: Influence of brine formation on Arctic Ocean circulation over the past 15 million years, Nat. Geosci., 1, 68-72, doi:10.1038/Ngeo.2007.5, 2008b.

Higgins, J. A. and Schrag, D. P.: Beyond methane: Towards a theory for the Paleocene-Eocene Thermal Maximum, Earth Planet. Sc. Lett., 245, 523-537, doi:10.1016/j.epsl.2006.03.009, 2006.

Huber, M. and Sloan, L. C.: Heat transport, deep waters, and thermal gradients: Coupled simulation of an Eocene Greenhouse Climate, Geophys. Res. Lett., 28, 3481-3484, 2001.

Jacobsen, S. B. and Wasserburg, G. J.: Mean Age of Mantle and Crustal Reservoirs, J. Geophys. Res., 85, 7411-7427, 1979.

Katz, M. E., Pak, D. K., Dickens, G. R., and Miller, K. G.: The source and fate of massive carbon input during the latest Paleocene thermal maximum, Science, 286, 1531-1533, 1999.

Kennett, J. P. and Stott, L. D.: Abrupt deep-sea warming, palaeoceanographic changes and benthic extinctions at the end of the Palaeocene, Nature, 353, 225-229, 1991.

Khélifi, N. and Frank, M.: A major change in North Atlantic deep water circulation 1.6 million years ago, Clim. Past, 10, 14411451, doi:10.5194/cp-10-1441-2014, 2014.

Koch, P. L., Zachos, J. C., and Gingerich, P. D.: Correlation between isotope records in marine and continental carbon reservoirs near the Paleocene Eocene boundary, Nature, 358, 319-322, 1992.

Kump, L., Bralower, T., and Ridgwell, A.: Ocean acidification in deep time, Oceanography, 22, 94-107, 2009.

Kurtz, A. C., Kump, L. R., Arthur, M. A., Zachos, J. C., and Paytan, A.: Early Cenozoic decoupling of the global carbon and sulfur cycles, Paleoceanography, 18, 1090, doi:10.1029/2003pa000908, 2003.

Lacan, F., Tachikawa, K., Jeandel, C.: Neodymium isotopic composition of the oceans: A compilation of seawater data, Chem. Geol., 300-301, 177-184, 2012.

Lunt, D. J., Valdes, P. J., Dunkley Jones, T., Ridgwell, A., Haywood, A. M., Schmidt, D. N., Marsh, R., and Maslin, M.: $\mathrm{CO}_{2}-$ driven ocean circulation changes as an amplifier of PaleoceneEocene thermal maximum hydrate destabilization, Geology, 38, 875-878, 2010.

Lunt, D. J., Ridgwell, A., Sluijs, A., Zachos, J., Hunter, S., and Haywood, A.: A model for orbital pacing of methane hydrate destabilization during the Palaeogene, Nat. Geosci., 4, 775-778, doi:10.1038/Ngeo1266, 2011.

Lunt, D. J., Dunkley Jones, T., Heinemann, M., Huber, M., LeGrande, A., Winguth, A., Loptson, C., Marotzke, J., Roberts, C. D., Tindall, J., Valdes, P., and Winguth, C.: A modeldata comparison for a multi-model ensemble of early Eocene atmosphere-ocean simulations: EoMIP, Clim. Past, 8, 17171736, doi:10.5194/cp-8-1717-2012, 2012.

Martin, E. E., Blair, S. W., Kamenov, G. D., Scher, H. D., Bourbon, E., Basak, C., and Newkirk, D. N.: Extraction of Nd isotopes from bulk deep sea sediments for paleoceanographic studies on Cenozoic time scales, Chem. Geol., 269, 414-431, 2010.

Martin, E. E., MacLeod, K. G., Berrocoso, A. J., and Bourbon, E.: Water mass circulation on Demerara Rise during the Late Cre- taceous based on Nd isotopes, Earth Planet. Sc. Lett., 327-328, 111-120, 2012.

McCarren, H., Thomas, E., Hasegawa, T., Rohl, U., and Zachos, J. C.: Depth dependency of the Paleocene-Eocene carbon isotope excursion: Paired benthic and terrestrial biomarker records (Ocean Drilling Program Leg 208, Walvis Ridge), Geochem. Geophy. Geosy., 9, Q10008, doi:10.1029/2008gc002116, 2008.

McInerney, F. A. and Wing, S. L.: The Paleocene-Eocene Thermal Maximum: A Perturbation of Carbon Cycle, Climate, and Biosphere with Implications for the Future, Annu. Rev. Earth Pl. Sc., 39, 489-516, 2011.

Murphy, B. H., Farley, K. A., and Zachos, J. C.: An extraterrestrial ${ }^{3} \mathrm{He}$-based timescale for the Paleocene-Eocene thermal maximum (PETM) from Walvis Ridge, IODP Site 1266, Geochim. Cosmochim. Ac., 74, 5098-5108, 2010.

Nunes, F. and Norris, R. D.: Abrupt reversal in ocean overturning during the Palaeocene/Eocene warm period, Nature, 439, 60-63, doi:10.1038/Nature04386, 2006.

Pagani, M., Pedentchouk, N., Huber, M., Sluijs, A., Schouten, S., Brinkhuis, H., Sinnghe-Damste, J., and Dickens, G. R.: Arctic hydrology during global warming at the Palaeocene/Eocene thermal maximum, Nature, 442, 671-675, 2006.

Paytan, A., Averyt, K., Faul, K., Gray, E., and Thomas, E.: Barite accumulation, ocean productivity, and $\mathrm{Sr} / \mathrm{Ba}$ in barite across the Paleocene-Eocene Thermal Maximum: Geology, 35, 1139-1142, doi:10.1130/G24162A.1, 2007.

Piotrowski, A. M., Goldstein, S. L., Hemming, S. R., and Fairbanks, R. G.: Intensification and variability of ocean thermohaline circulation through the last deglaciation, Earth Planet. Sc. Lett., 225, 205-220, 2004.

Piotrowski, A. M., Goldstein, S. L., Hemming, S. R., and Fairbanks, R. G.: Temporal relationships of carbon cycling and ocean circulation at glacial boundaries, Science, 307, 19331938, doi:10.1126/Science.1104883, 2005.

Piotrowski, A. M., Goldstein, S. L., Hemming, S., Fairbanks, R. G., and Zylberberg, D. R.: Oscillating glacial northern and southern deep water formation from combined neodymium and carbon isotopes, Earth Planet. Sc. Lett., 272, 394-405, 2008.

Ridgwell, A. and Schmidt, D. N.: Past constraints on the vulnerability of marine calcifiers to massive carbon dioxide release, Nat. Geosci., 3, 196-200, 2010.

Röhl, U., Westerhold, T., Bralower, T. J., and Zachos, J. C.: On the duration of the Paleocene-Eocene thermal maximum (PETM), Geochem. Geophys. Geosys., 8, Q12002, doi:10.1029/2007GC001784, 2007.

Rutberg, R. L., Hemming, S. R., and Goldstein, S. L.: Reduced North Atlantic Deep Water flux to the glacial Southern Ocean inferred from neodymium isotope ratios, Nature, 405, 935-938, 2000.

Scher, H. D. and Martin, E. E.:, Timing and climatic consequences of the opening of Drake Passage, Science, 312, 428-430, doi:10.1126/Science.1120044, 2006

Sluijs, A., Schouten, S., Pagani, M., Woltering, M., Brinkhuis, H., Damsté, J. S. S., Dickens, J., and Moran, K.: Subtropical Arctic Ocean temperatures during the Palaeocene/Eocene thermal maximum, Nature, 441, 610-613, 2006.

Sluijs, A., Brinkhuis, H., Schouten, S., Bohaty, S. M., John, C. M., Zachos, J. C., Reichart, G.-J., Sinninghe Damsté, J. S., Crouch, E. M., and Dickens, G. R.: Environmental precursors to rapid 
light carbon injection at the Palaeocene/Eocene boundary, Nature, 450, 1218-1221, 2007.

Stichel, T., Frank., M., Rickli, J., and Haley, B. A.: The hafnium and neodymium isotope composition of seawater in the Atlantic sector of the Southern Ocean, Earth Planet. Sc. Lett., 317-318, 282-294, 2012.

Storey, M., Duncan, R. A., and Swisher, C. C.: Paleocene-Eocene thermal maximum and the opening of the northeast Atlantic, Science, 316, 587-589, doi:10.1126/Science.1135274, 2007.

Svensen, H., Planke, S., Malthe-Sørenssen, A., Jamtveit, B., Myklebust, R., Eidem, T. R., and Rey, S. S.: Release of methane from a volcanic basin as a mechanism for initial Eocene global warming, Nature, 429, 542-545, doi:10.1038/Nature02566, 2004.

Thomas, D. J.: Evidence for deep-water production in the North Pacific Ocean during the early Cenozoic warm interval, Nature, 430, 65-68, doi:10.1038/nature02639, 2004.

Thomas, D. J., Zachos, J. C., Bralower, T. J., Thomas, E., and Bohaty, S.: Warming the fuel for the fire: Evidence for the thermal dissociation of methane hydrate during the Paleocene-Eocene thermal maximum, Geology, 30, 1067-1070, 2002.

Thomas, D. J., Bralower, T. J., and Jones, C. E.: Neodymium isotopic reconstruction of late Paleocene-early Eocene thermohaline circulation, Earth Planet. Sc. Lett., 209, 309-322, doi:10.1016/S0012-821x(03)00096-7, 2003.

Thomas, D. J., Lyle, M., Moore, T. C., and Rea, D. K.: Paleogene deepwater mass composition of the tropical $\mathrm{Pa}-$ cific and implications for thermohaline circulation in a greenhouse world, Geochem. Geophy. Geosy., 9, Q02002, doi:10.1029/2007gc001748, 2008.

Thomas, D. J., Korty, R., Huber M., Schubert, J. A., and Haines, B.: Nd isotopic structure of the Pacific Ocean 70-30 Ma and numerical evidence for vigorous ocean circulation and ocean heat transport in a greenhouse world, Paleoceanography, 29, 454-469, doi:10.1002/2013PA002535, 2014.

Tripati, A. K. and Elderfield, H.: Abrupt hydrographic changes in the equatorial Pacific and subtropical Atlantic from foraminiferal $\mathrm{Mg} / \mathrm{Ca}$ indicate greenhouse origin for the thermal maximum at the Paleocene-Eocene Boundary, Geochem. Geophy. Geosy., 5, Q02006, 1894-1898, 2004.
Tripati, A. and Elderfield, H.: Deep-sea temperature and circulation changes at the Paleocene-Eocene thermal maximum, Science, 308, 1894-1898, doi:10.1126/Science.1109202, 2005.

Winguth, A., Shellito ,C., Shields, C., and Winguth, C.: Climate Response at the Paleocene-Eocene Thermal Maximum to Greenhouse Gas Forcing-A Model Study with CCSM3, J. Climatol., 23, 2562-2584, doi:10.1175/2009jcli3113.1, 2010.

Zachos, J., Pagani, M., Sloan, L., Thomas, E., and Billups, K.: Trends, rhythms, and aberrations in global climate $65 \mathrm{Ma}$ to present, Science, 292, 686-693, 2001.

Zachos, J. C., Wara, M. W., Bohaty, S., Delaney, M .L., Petrizzo, M. R., Brill, A., Bralower, T. J., and Premoli-Silva, I.: A transient rise in tropical sea surface temperature during the Paleocene-Eocene Thermal Maximum, Science, 302, 15511554, doi:10.1126/Science.1090110, 2003.

Zachos, J. C., Röhl, U., Schellenberg, S. A., Sluijs, A., Hodell, D. A., Kelly, D. C., Thomas, E., Nicolo, M., Raffi, I., Lourens, L. J., McCarren, H., and Kroon, D.: Rapid Acidification of the Ocean During the Paleocene-Eocene Thermal Maximum, Science, 308, 1611-1615, 2005.

Zachos, J. C., Schouten, S., Bohaty, S., Quattlebaum, T., Sluijs, A., Brinkhuis, H., Gibbs, S., and Bralower, T. J.: Extreme warming of mid-latitude coastal ocean during the Paleocene-Eocene Thermal Maximum: Inferences from TEX86 and isotope data, Geology, 34, 737-740, 2006.

Zachos, J. C., Dickens, G. R., and Zeebe, R. E.: An early Cenozoic perspective on greenhouse warming and carbon-cycle dynamics, Nature, 451, 279-283, 2008.

Zeebe, R. E. and Zachos, J. C.: Reversed deep-sea carbonate ion basin gradient during Paleocene-Eocene thermal maximum, $\mathrm{Pa}-$ leoceanography, 22, PA3201, 2007.

Zeebe, R. E., Zachos, J. C., and Dickens, G. R.: Carbon dioxide forcing alone insufficient to explain PalaeoceneEocene Thermal Maximum warming, Nat. Geosci., 2, 576-580, doi:10.1038/ngeo578, 2009. 